Article

\title{
The Shift from Consumers to Prosumers: Susceptibility of Young Adults to Radicalization
}

\author{
Rahma Sugihartati ${ }^{1, *}$, Bagong Suyanto ${ }^{1}$ and Mun'im Sirry ${ }^{2}$ \\ 1 Faculty of Social and Political Sciences, Airlangga University, Surabaya 60115, Indonesia; \\ bagong.suyanto@fisip.unair.ac.id \\ 2 Department of Theology, University of Notre Dame, Notre Dame, IN 46656, USA; msirry@nd.edu \\ * Correspondence: rahma.sugihartati@fisip.unair.ac.id
}

Received: 4 March 2020; Accepted: 31 March 2020; Published: 3 April 2020

\begin{abstract}
This article examines the radicalization of young adults in relation to internet access and the social media content produced and managed by radical groups in Indonesia. Some of the research problems that become the major concern of this article were how young people respond to the internet and social media that provide radical content, how they find out about and access the content, what their purposes are for accessing radical content, and what they do with the radical content. The data discussed in this article were obtained from surveys and interviews with 700 students from seven state universities in Indonesia who were allegedly exposed to radicalism, according to the National Agency for Combating Terrorism (BNPT). The state universities that became research locations were the University of Indonesia (UI), Bandung Institute of Technology (ITB), Bogor Agriculture University (IPB), Diponegoro University (Undip), the Sepuluh Nopember Institute of Technology (ITS), Universitas Airlangga (UNAIR), and the University of Brawijaya (UB). This study revealed that in addition to accessing and consuming various radical content, some students also acted as prosumers. That is, they did not only read, but also produced information related to radicalization, and then recirculated it via social media.
\end{abstract}

Keywords: young adults; radicalism; consumers; prosumer; social media; susceptibility

\section{Introduction}

Young adults, including university students, are often targeted by radical groups to be recruited as cadres for radical movements around the world (Aiello et al. 2018; Alamsyah and Hadiz 2017; Doosje et al. 2013; Kortam 2017; Wong et al. 2019). They are recruited in many ways, especially through the utilization of cyberspace. In the digital age, the methods developed by these fundamentalists to spread radicalism are no longer via face-to-face interactions in the corporeal world. Instead, they take advantage of information technology and the internet. The developments of massive use of the internet, social media, and social networking applications are often exploited by these radical groups to spread radical ideologies, propagate doctrines, explore and recruit potential cadres, and even as a call for jihad against other groups which are considered to have caused much misery to Muslims (Bräuchler 2004; Aly et al. 2017; Rudner 2017).

A number of previous studies have examined the important role of social media and information technology as a primary means of spreading radical-religious ideologies and the impact of these ideologies on society, including the risks faced by young adults who are the largest users of information technology and the internet (Iqbal et al. 2016; Greenberg 2016; Klausen 2015; O'Hara and Stevens 2015; Conway 2017; Weng 2018), for example, states that terrorist groups often use social media to spread their ideology. The targets are mostly teenagers who actively use social media. These groups can manipulate teenagers to have radical thoughts and influence them to do radical things through 
the internet. When teenagers and young adults come home from schools or colleges, they no longer socialize with other people, and seclude themselves in their rooms instead. Unfortunately, this does not mean that they are completely safe from the influence of radicalization. Actually, in many cases, when young adults spend time in their rooms in front of smartphones or laptops, that is when they are exposed to temptations and offers, including radicalization. In the era of digital society, radicalization spread via social media and cyberspace is one of the threats faced by young people (Aiello et al. 2018).

Terrorism and the act of terror itself can be seen as a political phenomenon, and what makes it attractive is its allure as a life-mode or way of being (Cottee and Hayward 2011). In the United States, for example, the number of local extremists who call themselves The Islamic State in Iraq and the Levant (ISIL) continues to grow, because recruitment via the internet is getting more intense. ISIL uses the internet as a propaganda tool. They spread horrendous videos, books, and messages on Twitter. The target of radicalization is the Muslim youth in western countries. The use of the internet as a propaganda tool can cause hatred between religious communities, cause internet users to become racist and Islamophobic, and spread various conspiracies (Levin 2015). The success of Salafist extremists is proof that the internet can become a tool to radicalize and recruit youth to commit crime. An article written by Bhui and Ibrahim (2013) discusses the techniques of persuasion used by jihadist websites. They usually use various models of rhetoric, images, and symbols in text, video, and interactive formats. The media can be used as an information source, but can also be used as a technology to launch radical persuasions. By using the media, propaganda is used to attract both groups of pop culture fans and religious groups. Bhui and Ibrahim (2013) stated that the internet has failed to ward off the emergence of radicalization. On the contrary, the internet is often used as an instrument to spread the influence of radicalization.

This article focuses on the discussion about the access to radical content on online media held by students studying at public higher education institutions. The study was conducted in seven universities that were allegedly exposed to radicalization. The universities turned out to be public universities, in the sense that they were not religiously affiliated universities. This article intends to explain not only how young people in Indonesia are exposed to radicalism offered via various sites in cyberspace, but also the risks faced by young people when they are exposed to radicalism. Although the number is not too large, students who are exposed to radicalism in cyberspace are not just passive consumers, but they also have the potential to become prosumers, or active cadres, who disseminate radicalism as part of their mistaken beliefs.

\section{Literature Review}

Young adults in the 21st century are basically part of the virtual generation or also called the Net Generation. On the one hand, they enjoy conveniences of information technology and the internet, but on the other hand, they are also vulnerable to the contamination of negative content from cyberspace. Alch (2000), who specifically studies the Net Generation, states that this generation needs to obtain information as quickly and as easily as possible, to spend a lot of time to them selves, and not to be restrained in their lives. Tapscott (2009) mentioned some of the characteristics of the Net Generation, which are: (1) freedom; (2) customization; (3) scrutiny; (4) integrity; (5) collaboration; (6) entertainment; (7) speed; and (8) innovation. That is, behind the convenience felt by young adults in accessing information on the internet, there is a hidden risk. Young adults who are increasingly accustomed to surfing in cyberspace turn out to be exposed to a variety of harmful information content, such as radicalism.

The problem is that radical groups, including terrorist groups, realize that the internet is a powerful tool that can be used to achieve their strategic goals. Modern terrorists became aware of the new opportunities not only to exert mass psychological impact, but also to transmit messages more easily and freely to huge audiences (Weimann 2005). Various radical groups increasingly use the internet and social media as a means to spread their influence. Benigni et al. (2017) argue that ISIS often used social media as a medium to spread their ideology and seek support. On Twitter, 'retweet' 
propaganda is used by ISIS as a primary way of gaining support and carrying out independent terrorist cell attacks. Young adults, who are the largest users of social media, are targets that are part of the online extremist community (OEC). Martin Rudner (2017) used the term "electronic jihad" when he analyzed the way Al-Qaeda used the internet as an influential catalyst for the actual recruitment of jihadist operatives. Furthermore, Rudner contends that the internet and social media have emerged to become increasingly important mechanisms for Al-Qaeda's fund-raising and financial transfers to support terrorist activities.

Indeed, scholars are still debating how much of an influence the internet is in the process of radicalization. On one spectrum, a number of scholars are sceptical that the internet brings as much real impact as a face-to-face interaction does. Laqueur (1993) is sceptical about the transferability of virtual power into real power. Burke (2011) similarly, argues that social media does not have a significant effect on the real world. Those sceptical experts argue that the role of the internet in facilitating terrorist training is overestimated. Hegghammer (2012) also argues that it is unlikely that a recruiter would be able to successfully complete the screening process using only remote online communication. At the heart of the sceptics' argument is the view that the influence of online media cannot be equated with "grassroots activism", which is activism in the real world.

Meanwhile, on another spectrum, some scholars emphasize that the influence of the internet is now more powerful than is generally assumed. The "electronic jihad" referred to by Rudner (2017) has an impact that is not only real, but also broad. Even though it remains unclear how the Internet contributes to the radicalization process, a study by King and Taylor (2011) on theoretical models of homegrown Jihadists proposes that the Internet facilitates interpersonal relationships and group interactions that somehow replace established organizations in terms of direct contact with their followers. They also add that the Internet acts as a 'virtual incubator' for radicalization. Through online web forums, the Internet mirrors several functions otherwise fulfilled by established organizations. Firstly, it provides ideological support for people who seek it. People do not only consume the narrative, but they can also contribute to the discourse (Drennan and Black 2007; King and Taylor 2011). Secondly, the Internet acts as a platform that enables like-minded individuals to interact with each other, for instance to carry out an actual attack (Choudhury 2007; Kirby 2007) Thirdly, the Internet supplies information and educational materials that promote radical ideologies, with an example of the Al-Qaeda organization that published an article on a self-made bomb, titled "Make a Bomb in the Kitchen of Your Mom" on the first volume of their magazine, Inspire (The AQ Chef 2010). Those who are sceptical about the real influence of the internet are considered unaware that social media also has a social aspect, as implied by Maura Conway (2017):

Apart from the debate, it cannot be denied that in reality, terrorist groups such as Al-Qaeda and ISIS have used the internet and social media to spread their extreme ideology and carry out recruitment process and fundraising. Many studies have shown that thousands of websites were created and controlled by radical jihadist group (Denning 2001; Conway 2006; Lieberman and Collins 2008; MacDonald and Mair 2015) ISIS was known to develop and manage the internet and social media in a sophisticated way. They were particularly active and successful in recruiting foreign fighters, especially from Europe and the United States, by using Twitter, YouTube, Diaspora, and other online social networks. Of course, there are variations in the purpose of using online media. In his research on Al-Shabaab in Kenya, Mair (2016) revealed that this terrorist group used Twitter with the primary purpose of creating a narrative that sided with their movement.

The Internet is a truly revolutionary contribution that has abled to transform the propaganda dimension of terrorist groups — turning their"age-old dream of direct, intermediary-free communication with their potential "public" into a reality" (Smith et al. 2016, p. 6). A number of scholars further elaborate on the fact that the Internet can be used for data mining, networking, recruitment, planning, mobilization, and fund-raising (Cetina 2005; Michael 2013; Weimann 2005). The utilization of the internet and social media is not only monopolized by the congregation of terrorists. Many radical 
preachers also use online media to spread hatred that influences young adults. In her article, "The Call to Jihad: Charismatic Preachers and the Internet", Gendron (2017) highlighted the role of online media in spreading radical ideas by a number of Muslim figures. Gendron pointed out that the most vulnerable parties to the charisma of religious leaders are the younger generation. She wrote:

It seems that charismatic preachers have succeeded in exploiting the problems of young adults and making them the main target of their online sermons. Between the confusion of searching for identity among the younger generation and the charisma and popularity of the preachers, there is a connector named online media. (Gendron 2017)

Then, how do young adults respond to the charismatic preachers' online sermons and other radical content on social media? How do they find out and access the sermons and radical content? What did they do with the radical content? So far, not too many studies have addressed these questions, because more attention has been paid to the utilization of the internet among radical individuals and groups, not to the reaction of the targeted audience. Regarding the radicalization of young adults, a number of studies have focused more on answering the question of why they are vulnerable to being recruited by terrorists and radical groups via online networks. Several studies have identified a number of problems that cause the youth's vulnerability to radicalization, including education issues, identity crisis, and questions of belonging or fitting in or loyalty in secular western societies. A study by Silke (2008) found that psychological processes and group dynamics have a large role in understanding the development of radicalization among some Muslim youth. According to Farrington (2003), there are several factors that lead young people under 20 years to join terrorism, namely individual, family, socio-economic, and school factors. Meanwhile, a study conducted by Delia Deckard and Jacobson (2015), which studied the Muslim community in Western Europe, found that radicalization was more precisely associated with alienation than with poverty.

This study will portray a different aspect, namely how young adults learn of media with radical content, why they access the media, for what purpose they access the media, and what they do after that. To answer these questions, field research was conducted at seven well-known state universities in Indonesia, namely the University of Indonesia (UI), Bandung Institute of Technology (ITB), Bogor Agriculture University (IPB), Diponegoro University (Undip), the Sepuluh Nopember Institute of Technology (ITS), Universitas Airlangga (UNAIR), and the University of Brawijaya (UB). The significance of this research lies, for one thing, in cases that did not occur in western countries, so this research is expected to enrich that perspective. Indonesia is the world's most populous Muslim-majority country that has made it through the democratic transition. The country known as "Muslim smiling faces" is experiencing what some scholars call "conservative turn" (Bruinessen 2013; Fealy 2007) and religious intolerance. This phenomenon also has an impact on the younger generation, one of which is a result of the influence of the use of social media on a massive scale.

\section{Methods}

All research data were obtained from surveys and interviews with 700 students from 7 prominent state universities in Indonesia (see Table 1). These seven state universities were selected as research locations because these universities were allegedly infiltrated by a radicalization, according to the National Agency for Combating Terrorism. Therefore, those academic institutions have also been actively involved in organizing programs and developing new approaches to combat radicalization. In each university, 100 students were interviewed, bringing the total number of students interviewed to 700 . 
Table 1. Respondents and Informants of the Research.

\begin{tabular}{cccc}
\hline University & City & $\begin{array}{c}\text { Number of } \\
\text { Respondents }\end{array}$ & $\begin{array}{c}\text { Number of Informants } \\
\text { of In-Depth Interview }\end{array}$ \\
\hline University of Indonesia (UI) & Depok, West Java & 100 students & 10 students \\
\hline Bogor Agriculture University (IPB) & Bogor, West Java & 100 students & 10 students \\
\hline Bandung Institute of Technology (ITB) & Bandung, West Java & 100 students & 10 students \\
\hline Diponegoro University (Undip) & Semarang, Central Java & 100 students & 10 students \\
\hline Universitas Airlangga (Unair) & Surabaya, East Java & 100 students & 10 students \\
\hline $\begin{array}{c}\text { Sepuluh Nopember Institute of } \\
\text { Technology (ITS) }\end{array}$ & Surabaya, East Java & 100 students & 10 students \\
\hline University of Brawijaya (UB) & Malang, East Java & 100 students & 10 students \\
\hline Total & & 700 students & 70 students
\end{tabular}

In the process of selecting respondents, this study conducted interviews by selecting students who met the following criteria:

(1) Active students at state universities.

(2) Actively involved as an administrator and member of religious activities on campus in the past year.

(3) Accessing sites that are classified as radical in the past year.

(4) Part of the Net Generation, owning gadgets that can be used to access radical sites.

In addition to conducting structured interviews based on questionnaire, this study also conducted in-depth interviews. In-depth interviews were conducted with 70 students who had interesting experiences in accessing radicalism sites.

All data from 700 respondents were processed using SPSS. The data is displayed in the form of a frequency table, to see patterns of consumption and production activities of radicalism content among students of state universities in Indonesia.

\section{Results}

Young people, especially students, are no longer just passive audiences that merely consume radical content asymmetrically, but they often also actively participate in producing radical content to be recirculated to other groups. Unlike terrorist groups who deliberately use the internet to carry out psychological warfare and develop their radical ideology (Amble 2012; Conway 2017), some state university students are also known to be involved in the process of production and dissemination of radical content. The "spreadable" nature of convergent media enables students to become producers and consumers of appraisers, as well as distributors of radical content that they believe in.

Spreadability here is an alternative terminology in cultural studies that is now widely used to describe how audiences are involved with and become active agents in spreading media content in the process of content circulation. Spreadability emphasizes technical affordances that make it easier to circulate some types of media content, social networks, or links, where people get together through meaningful exchange of bytes and with various motives that encourage them to share content or information to fellow members of the cyberspace community (Green and Jenkins 2011). Spreadability allows the placement of an almost unlimited and multiplying amount of information via network and process of circulation of media content. Spreadable media encourage the cyberspace community to be deeply involved with media messages by encouraging them to engage in online media message circulation (Green and Jenkins 2011).

The study found that more than half of students of state universities tended to not only consume radical content for themselves $(41.3 \%)$, but to varying degrees of intensity, they also often circulated 
the radical content they received. This means that strategies developed by radical groups that use social media and the internet to disseminate their radical ideology have achieved the results expected (Aly et al. 2017). As many as 35.2\% of respondents claimed to infrequently circulate radical content to other groups, $21.6 \%$ of respondents claimed to frequently circulate radical content to other groups, while the remaining $1.9 \%$ of respondents claimed to always circulate the radical content they received to other people (see Table 2). This is what is meant by the involvement of young adults as a "prosumer" of radical content. They generally do not produce the content by themselves, but actively participate in spreading radical content they found on online media networks. The practice of radical streaming done by students is also due to their ignorance and sometimes naivety, as they do not fully understand its seriousness.

Table 2. Involvement in Circulating Radical Content.

\begin{tabular}{lcc}
\hline \multirow{2}{*}{$\begin{array}{l}\text { Do respondents frequently } \\
\text { circulate/recirculate radical } \\
\text { content to others? }\end{array}$} & Always & $1.9 \%$ \\
\cline { 2 - 3 } & Frequently & $21.6 \%$ \\
\cline { 2 - 3 } & Infrequently & $35.2 \%$ \\
\hline When accessing radical content, do & Believing without confirming & $41.3 \%$ \\
\cline { 2 - 3 } $\begin{array}{l}\text { respondents further seek out the } \\
\text { authenticity of the information? }\end{array}$ & $\begin{array}{c}\text { Unsure about the authenticity of the } \\
\text { information }\end{array}$ & $9.00 \%$ \\
\cline { 2 - 3 } & Not believing & $28.9 \%$ \\
\hline
\end{tabular}

A number of students during the in-depth interviews claimed that they did not care about other people's opinionsof content that was classified as radical, because according to those students, that was what they believed.

"I often read information and news about the suffering of Muslims who are victims of Israeli and American atrocities. Trump's phobia to Muslims has also been reported everywhere. Such Information [is the kind of information] that I often share with other friends. Let us be fair in dealing with cases like this. In my opinion, fighting the aggression of countries that are hostile to Muslims, one of which is through a war on social media. It's a matter of how to prevent American propaganda from developing. [American propaganda] must be countered ... " Rudi (20 years old, University of Indonesia)

"If people don't like us, surely we are said to be radical. Even though it's our belief. Our religion is actually full of love. Let people not continue to prosecute us, so we must be tactical too. I send news to groups or to other friends without any purpose. [When] I read it [and I think] the content is good, I share it with friends ... " Asti (19 years old, Universitas Airlangga)

Those students have actually been in touch with radicalism only for a short time. According to the confessions of students studied, 33.4\% claimed to have known radicalism less than 6 months. However, quite a lot of students have known radicalism for more than 24 months or 2 years (22.2\%). As many as $23.3 \%$ of respondents claimed to have known radicalism for around 19-24 months, and $19.3 \%$ of respondents said they only knew radicalism for about $7-12$ months (see Table 3 ). Theoretically, the more intense the contact of students with radicalism via the internet is, the greater the possibility to grow into radical young adults becomes. For radical groups like Al-Qaeda, the virtual world is like a kind of an effective virtual training camp (Stenersen 2008). It is not impossible for the Net Generation to be influenced and grow into radical individuals as they become more intensely in touch with radical content in cyberspace. A study conducted by Aly (2012), for example, found that the internet plays a role in individual radicalism towards extremism, which justifies violence. 
Table 3. Intensity and Motives of State University Students to Access Radical Sites.

\begin{tabular}{|c|c|c|}
\hline \multirow{5}{*}{$\begin{array}{l}\text { How long has the respondent } \\
\text { started accessing sites that provide } \\
\text { radical content? }\end{array}$} & Less than 6 months & $33.4 \%$ \\
\hline & 7-12 months & $19.3 \%$ \\
\hline & 13-18 months & $1.8 \%$ \\
\hline & 19-24 months & $23.3 \%$ \\
\hline & More than 24 months & $22.2 \%$ \\
\hline \multirow{4}{*}{$\begin{array}{l}\text { The intensity of respondents in } \\
\text { accessing radical sites }\end{array}$} & Always (every day) & $15.1 \%$ \\
\hline & Frequently (at least once in a week) & $24 \%$ \\
\hline & Infrequently (at least once in a month) & $25.9 \%$ \\
\hline & $\begin{array}{l}\text { Very infrequently (Often not accessing } \\
\text { at all for a month) }\end{array}$ & $35 \%$ \\
\hline \multirow{4}{*}{$\begin{array}{l}\text { The motive of respondents in } \\
\text { accessing sites that provide radical } \\
\text { content }\end{array}$} & Curiosity & $51 \%$ \\
\hline & Being interested in learning more deeply & $31 \%$ \\
\hline & $\begin{array}{l}\text { To learn/understand the purpose of } \\
\text { radical movements }\end{array}$ & $10.3 \%$ \\
\hline & To find materials to circulate & $7.7 \%$ \\
\hline \multirow{4}{*}{$\begin{array}{l}\text { How do respondents know about } \\
\text { radical sites? }\end{array}$} & Searching by themselves & $21.7 \%$ \\
\hline & From friend & $36.4 \%$ \\
\hline & From seniors recruiting them & $15.6 \%$ \\
\hline & Finding it accidentally & $26.3 \%$ \\
\hline
\end{tabular}

The intensity of students accessing sites providing radicalism content was mostly classified as "very infrequently" (35\%). However, this study found as many as $15.1 \%$ of respondents claimed that they always spent time accessing radical sites every day, and as many as $24 \%$ claimed to access radical sites at least once a week. As many as $25.9 \%$ accessed radical content about once a month. For the students, the chances of coming in contact with radical content are huge, because every day they generally always access the internet, and it is not impossible that some of the information accessed is from a site that contains radical content (Afrianty 2012). Weng (2018) found that one of the sites that were popular among young adults was owned by Felix Siauw, who was said to be radical but had millions of followers who enjoyed his sermons.

"Learning Islam can be via any media. Islam is broad, so I start from reading on social media or dakwah accounts. Now there are many [dawah accounts]. I read [contents] that are relevant to my life first, from the light issues first, for example, human relations in Islam, men-women relations. So, I just found out that there must be a separation in relationships between men and women, except for three things, in terms of buying and selling in the market, health, and education. Then, dating is not allowed, even though there is the so-called Islamic dating, it is still not allowed in Islam. And from there, I understand how a Muslim interacts with the opposite sex. I just understood, it turns out that Islam teaches about all things, not only prayer, fasting, alms, but also every scope of human life. There are rules, for example, the rules of relation between men and women. Finally, I was interested to study deeper. I also followed the sermons of Ustād Felix, because I thought he was cool. He was a non-believer then converted to Islam. Even though he has just become a convert, his knowledge about Islam can educate Muslims who were born Muslims. [He is] just great and the books that Mr. Felix wrote are cool. I sometimes like to post his posts on my timeline. There are also other preachers I keep up with, such as Ustād Abdul Somad and Mr. Zulkifli, but I only watch their sermons from YouTube." Dennis (21 years old, Universitas Airlangga) 
The motives of students to access radical sites were large because of curiosity (51\%). Various platforms in cyberspace and the presence of social media open up many opportunities for students to search and find the information they want, including information about radical movements. Platforms like Twitter and Facebook often become media that are used by radical groups to attract cadres. Boko Haram, for example, is one of the radical groups that have a Twitter account to offer radical discourse and violence, which are part of their ideology (Chiluwa 2015). Although in various countries there has been a de-radicalization, it is not an easy problem (Aistrope 2016). As many as 31\% of respondents claimed to access radical sites because they were interested in exploring the radical ideology they knew, and $10.3 \%$ claimed they were interested in exploring radical sites to study the aims of radical movements. What is interesting about this study was that $7.7 \%$ of respondents accessed radical sites to find material to be circulated or recirculated further. A number of informants claimed that they really enjoyed reading and spending their free time tracking religious information. Even though the information they were searching for was said to be radical, they stated that it was no problem because, according to them, the problem was the perspective of others who were judgmental and not objective.

"Islam is often said to be radical. Those who attack the whole community of Muslims are not labeled with' radical'. So, in my opinion, [the term]'radical' depends on the interests. If [they want to] call me' radical', let them be. The important thing [for me] is to be objective, not radical. Islam clearly teaches respect to others. If people don't know Islam, it is easy for them to promote baseless accusations. If they already know [Islam], they will definitely change their attitude..." Najwa (18 years old, University of Brawijaya)

The source of information about radical sites, according to most respondents, was from friends (36.4\%). As many as $26.3 \%$ of respondents claimed to know radical sites by accident. When they were browsing, it turned out they actually found sites that provided radical content. For many radical groups, the internet has long been used as a medium to spread the radical ideas they believe in. YouTube, for example, is a platform that is often used to spread neojihadism and especially to create groups that will militantly fight for the religion (Andre 2012). As many as $15.6 \%$ of respondents claimed to know the radical sites from their seniors, who recruited them to be actively involved in activities classified as radical. As many as $21.7 \%$ of respondents claimed to know radical sites by searching on their own on various sites in the unlimited virtual world.

Radical content that had often been accessed by most students (32.1\%) was news about the conditions of Muslim communities in many countries. Generally, those Muslim communities are victims of war. As many as $22.1 \%$ of respondents said they often accessed radical content that discussed khilafah movement, and $22.3 \%$ of respondents claimed to often access news related to the treatment of western countries to Middle Eastern countries (see Table 4). Even though Indonesia is not governed by Islamic law, the Khilafat (Caliphate) movement is still prevalent in the country (Bruinessen 2013). Some argue that in today's context, the movement is associated with radical links to the Middle East. Historically speaking, the radical Islamic movements in Indonesia are not a new phenomenon, but have been present since the colonial era (Reid 1967). However, in Soekarno's secular movement, there was no room for an Islamic State. Nowadays, the radical religious groups that stayed in Indonesia are kept underground, and are mostly focused around university campuses.

Table 4. Radical Content Accessed by State University Students.

\begin{tabular}{cccc}
\hline Accessed Radical Contents & Frequently & Infrequently & Never \\
\hline Information about ISIS & $6 \%$ & $20 \%$ & $74 \%$ \\
Information related to bomb-making & $2.30 \%$ & $14 \%$ & $83.70 \%$ \\
Khilafatmovement & $32.10 \%$ & $36.90 \%$ & $31 \%$ \\
The conditions of Muslim communities in many countries & $22.10 \%$ & $57.60 \%$ & $20.30 \%$ \\
The way western countries treat middle east countries & $22.30 \%$ & $36.30 \%$ & $41.40 \%$ \\
\hline
\end{tabular}


Not many respondents often accessed sites to find information about ISIS (6\%). Although the number was insignificant, this study found that $2.3 \%$ of respondents claimed to frequently access information about bomb-making instructions. The fact that these young adults often accessed sites related to bomb-making instructions is certainly alarming, no matter how many the number was. It is not impossible that the information will mislead them to acts of violence. The results of the study conducted by Hwang (2017) showed that among jihadist groups, carrying out jihadi actions are generally seen as part of the struggle relating to their beliefs in order to take the path of God.

The types of radical content that were often accessed by students were generally in the form of articles (34.7\%) and videos (32.7\%). As many as $24.5 \%$ of respondents claimed to often access radical content in the form of news on various sites. Meanwhile, as many as $18.3 \%$ claimed to frequently access information in the form of memes, and $18.1 \%$ in the form of pictures or photographs (see Table 5). Reading articles and then interpreting them based on ideological preferences often leaves young adults trapped in the ideology of radicalism without them knowing it (Mietzner and Muhtadi 2018). According to an analysis by Weimann (2005), contents posted by radical or terrorist organizations have so far attempted to target not only potential supporters or enemies but especially 'bystander' public and surfers who are not involved in the conflict. Conway (2017) stated that in Syria, the Islamic State (IS) has proven to be successful in reaching young women and bringing up the flow of 'jihadi brides' online. Similar online calls for families to migrate to the caliphate are also increasing. A series of unusual types of terrorist attacks, such as running over people by car and knife stabbing, appear to be influenced by online calls.

Table 5. Radical Contents that Have Been Accessed by Students.

\begin{tabular}{cccc}
\hline Type of Radical Content Accessed & Frequently & Infrequently & Never \\
\hline News & $24.5 \%$ & $35.5 \%$ & $40 \%$ \\
Memes & $18.3 \%$ & $35.4 \%$ & $46.3 \%$ \\
Picture/photo & $18.1 \%$ & $43.8 \%$ & $38.1 \%$ \\
Article & $34.7 \%$ & $32.1 \%$ & $33.2 \%$ \\
Video & $32.7 \%$ & $36.5 \%$ & $30.8 \%$ \\
\hline
\end{tabular}

Besides accessing and consuming various radical contents, this study found that some students also acted as prosumers. That is, these students did not only read information containing radical content, but they also produced radical information and then recirculated it via social media. Although most students claimed to have never produced radical content, this study found that $8.5 \%$ of respondents claimed to often produce radical content in the form of posters. According to Table 6, many as 5.3\% of respondents produced radical content in the form of exhortation or invitation, and $3.4 \%$ in the form of information or news whose content was radical. The contents were then circulated to others. The group of students in state universities that do not only consume but also produce radical content is a group of young people who would possibly engage in jihad if they had chance and there was a trigger factor.

Table 6. Radical Content Created by Students.

\begin{tabular}{cccc}
\hline Radical Contents That Have Been Created & Frequently & Infrequently & Never \\
\hline Poster & $8.5 \%$ & $11 \%$ & $80.5 \%$ \\
Memes & $0.9 \%$ & $2.4 \%$ & $96.7 \%$ \\
Information/new & $3.4 \%$ & $3.2 \%$ & $93.4 \%$ \\
Video & $1.4 \%$ & $2 \%$ & $96.6 \%$ \\
Invitation/exhortation & $5.3 \%$ & $2.4 \%$ & $92.3 \%$ \\
Figure profile & $1.7 \%$ & $3.9 \%$ & $94.4 \%$ \\
Sermon & $1.7 \%$ & $3.9 \%$ & $94.4 \%$ \\
Story of struggle & $2.4 \%$ & $4 \%$ & $93.6 \%$ \\
\hline
\end{tabular}


Some of the students in this study were known to have the ability to operate technological devices, and they were also accustomed to creating various content to be distributed incyberspace. Making posters or editing existing posters that they obtained from the sites, and adding additional information so that the display becomes more interesting, is what some informants do. When they were interviewed, a number of students openly showed their work in the form of posters or invitations to fight for the freedom of Muslims, which they said to be victims of Israeli atrocities. The freedom of the Palestinian people was one of the issues that were often discussed and fought for by some students when they produced and disseminated content to social media.

“Every Thursday night, we usually make a tweet storm. We bombard Twitter with \#Khilafah.

One of our goals is for the media to know that we still exist. Even though [we were] disbanded, we are still here." Imam (21 years old, Diponegoro University)

This study found that a number of students were known to often use social media to share Islamic content that they created themselves or obtained from other sources. They were also actively involved in the WhatsApp groups to coordinate and share information related to sermons and content they have created. In adding prospective new members, for example, a number of informants along with other members often created small groups on social media such as WhatsApp. These groups generally began with a study group that discusses general issues and figh, which were considered relevant to the daily life of prospective members. If prospective members were deemed ready, they would be invited to attend a "heavier" level of sermon.

As content producers, students who had visual communication design skills often created videos, posters, and memes in order to promote their sermon activities or other activities. It was also as an ongoing and scheduled internalization effort via their social media. Image content was scheduled to be posted once every two days, and video content was posted at least once a month. Content material that was shared also varied, ranging from the lightest discussion about the anti-dating movement, to discussion of the caliphate-state system. Students took advantage of share culture among social media users. Lately, social media users are more active in sharing information via groups because of the increasing share culture. From interviews, it is known that when a number of students shared religious content, they usually added the call "Spread this information" or other bombastic words. Some used the phrase "Share with others, don't stop at you". All of this was done by the informants, so that the content they produced did not stop at only one or two people, but could be shared further with many other people in order to garner sympathy and support.

At Diponegoro University, for example, a number of WhatsApp and Line groups participated in by students involved in radical-indicated activities were exclusive. After the universities limited radical movements of students, radical student groups were more focused on retaining existing members, rather than recruiting new ones. This was because they were trying to strengthen the ideology and solidarity of the members. Nevertheless, each member still shared information, content, or opinions via their personal social media accounts in more subtle words, so as not to provoke stricter regulatory actions from the university.

\section{Discussion}

The results of this study have shown that the radicalization of young adults was not only the impact of their commitment to radical ideology as a consequence of face-to-face indoctrination carried out by certain religious leaders or radical groups in certain locations, but also as a consequence of indoctrination via electronic media that can be accessed openly and disseminated. In other words, acts of violence and militancy among young adults are not merely a consequence of their psychological condition and personality background, but also a result of the susceptibility of young adults to radicalism from social media and cyberspace. Terrorism in modern times is aware that social media can be used to carry out acts of terror. Some terrorist organizations use social media to carry out terror attacks and target many victims (Weimann 2005). Students, who are in fact part of the Net Generation 
are generally vulnerable to radicalism, which is widely disseminated via cyberspace by radical groups from other countries.

At the present time, social networking sites deliberately designed by certain individuals and groups are widely circulated to educate, indoctrinate, and persuade those who wish to explore various options and to search for alternatives to their beliefs all this time. The potential threat from the dissemination of radical content sites has been recognized by policymakers. Raffaello Pantucci was right when he wrote:

"The increasing prevalence of the internet and the easy availability of extremist material online have fostered the growth of the autodidactic extremist." (Pantucci 2011)

Indeed, not all students who are exposed to radicalism via cyberspace will be contaminated and turned into militants and radicals. However, starting from trial and error, and driven by curiosity, some young people sometimes unwittingly become more radical. More than just passive consumers of content from social media and internet accounts promoting radicalism, some students turned out to be active consumers and even producers of radical content, which they then recirculated on social networks. This study found that, as part of the Net Generation, young adults are not only susceptible to radicalism, but often they also become an extension of the voice and participate in recirculating the ideology of radicalism in various ways. In the digital age, young adults are prosumers of radicalism who have the potential to spread their beliefs on an extraordinary scale.

A study conducted by Pedersen et al. (2018) of 8627 teenagers in Oslo, Norway, found that Muslim youth in Oslo were more likely to support the use of violence to obtain social change compared to other adolescents. However, after controlling for several other variables, Islam did not have a significant relationship with providing support for political violence. The complex background of immigrants and the emergence of teenage outsiders, which is a result of underachievement in schools, has sparked various problems of violence in certain Muslim teenagers. Political activity on social media also has an important role in influencing teenagers' behavior to commit violence and jihadism. In this case, an emerging 'outsider position', rather than being Muslim, becomes the underlaying cause. Further efforts are needed to prevent the radicalization of teenagers or young adults who are at risk of becoming teenage outsiders.

It would not be easy to prevent or eliminate the possibility of young adults being exposed to radicalism and becoming militant. As Al-Zewairi and Naymat (2017) have said, in recent years, terrorist and separatist groups have begun to actively use new technologies as media to widely spread their ideology. Meanwhile, Stenersen (2008) stated that in the digital age, the internet has functioned as a substitute for real-life training, especially in the case of homegrown terrorists whose operations do not require networks, contacts, or trips to train abroad, because those methods are perceived to be too risky. It is this online recruitment of terrorist cadres that makes prevention efforts difficult.

This research also identified students of public universities, not students of religiously affiliated universities, as targets of radical group recruitment. This finding was in line with Gendron (2017) who stated:

"Recruiters seek out high school and college students, those living in isolated areas away from the big cities, and prefer the non-religious over the religious because they consider those ignorant of the tenets of Islam to be more susceptible to guidance and indoctrination."

However, differing from Gendron's findings, this research revealed that students who were exposed to radicalism actually came from leading universities located in cosmopolitan cities. That is understandable because, in urban areas, the internet and social media can be very easily accessed. The emphasis of the results of this study is the activity of young adults who are quite active as prosumers of social networks by circulating radical content. We also found a kind of paradox in their attitudes towards radical content. Even though more than half of respondents spread radical content on different levels, where some were more active than others, the number of respondents who did not 
believe in the validity of radical content was quite high, namely $62.1 \%$, and only $9 \%$ of respondents who admitted to believing the validity of radical content. When they were further asked whether they clarified to ensure that certain radical content was not a hoax, respondents who answered affirmatively amounted to $84.2 \%$. That means that even though the radical content is actually a hoax, young adults will tend to share it anyway.

Another interesting thing about the "power" of internet-based propaganda is the virtual space that allows young adults to admire certain figures that challenge the traditional authority. In Indonesia, authoritative $d a^{\prime} i$ figures, especially those from traditional Islamic education (pesantren), are not active in cyberspace. Conversely, $d a^{\prime} i$ who have strong Islamic educational backgrounds appear to dominate virtual space. When the respondents were asked whose social media accounts they followed, $35.1 \%$ of respondents mentioned Felix Siauw, a Chinese Muslim convert who joined the Indonesian Hizbut-Tahrir (HTI). Because of its ideology that wants to replace Pancasila (five principles) with the khilafat ideology, HTI has been officially disbanded by the Indonesian government. It is interesting to note that Siauw has no background in religious education at the moment, but his sermons, which emphasize the aspects of tyranny that represses Muslims and call for the system of khilafaf as a solution, seem to be quite appealing to the younger generation. The second figure loved by young adults exposed to radicalism is Zakir Naik (18.1\%), an Indian preacher who now lives in Malaysia. Like Siauw, Naik did not have an education background from traditional Islamic Madrasah in his home country, Pakistan. He is actually a medical doctor but actively uses social media to do dakwah. Thus, young people become distant from their religious roots, grappling with issues of identity, social deprivation, and status, and reject both the authority of their parents and these mainstream Imams (Gendron 2017).

The problem now is how to develop counter-radicalization via the internet to eliminate the influence of radicalism among young adults. As it is known, the internet is a massive communication medium used today. Today, terrorist groups can easily spread their teachings via the internet. Therefore, difficult questions need to be raised:

1. In the era of freedom of information, can radical propaganda be limited or monitored? If it can be limited or monitored, how?

2. What rules are available, both at the nation-state level or to the server owner, which allow us to control and ban radical content?

3. Is it time for the fight against technologically advanced terrorism to be concentrated at its informational source?

For radical terrorist organizations, the Internet provides a global, yet also highly individualist, way for terrorist groups to communicate with their target audiences, current and potential supporters, as well as their enemies (Smith et al. 2016). Greenberg (2016) argued that in order to guarantee security on the internet, three things must be considered in combating radicalization. Those three things are disruption, diversion, and counter-messaging. It is based on the belief that the internet is like a double-edged knife. It can be used to spread radical and extreme propaganda, but at the same time, it can also be used to cease it.

\section{Conclusions}

As part of the Net Generation, university students generally encounter dilemmatic situations. On the one hand, they enjoy the convenience of accessing information from the limitless virtual world, but on the other hand, they are also prone to be contaminated with radicalism spread by hardliners from around the world. Besides accessing and consuming various radical content, this study found that some students also acted as prosumers. That is, do did not only read but also produce radical information, and then recirculate it via social media. Students exposed to radicalism via the internet are at risk of becoming more radical and militant and becoming supporters or cadres of radical movements. The findings of this study are in line with the conclusions of Rachel Briggs and Sebastien Feve, who stated that the internet is an important part of the radicalization process, in 
most cases intensifying and accelerating radicalization (Briggs and Feve 2014). Intensification and acceleration are possible because of the nature of online platforms that know no boundaries with high levels of connectivity. Of course, it is not fair to point fingers toward the Internet as a lone culprit for radicalization, but serious efforts are needed to protect young people from the risk of falling under the control of radical groups and terrorists.

Author Contributions: R.S. designed and conceptualized the research and provided the main data theoretical analysis. B.S. analyzed data, co-wrote the article and collected the data. M.S. co-wrote the paper and contributed to additional theoretical analysis to the data. All authors have read and agreed to the published version of the manuscript.

Funding: This research was funded by Tahir Foundation and The APC was funded by Tahir Foundation.

Acknowledgments: The authors would like to thank Dato' Sri Tahir, the founder of the Tahir Foundation, for this research was fully supported by the grant from the Tahir Foundation.

Conflicts of Interest: The authors declare no conflict of interest.

\section{References}

Afrianty, Dina. 2012. Islamic education and youth extremism in Indonesia. Journal of Policing, Intelligence and Counter Terrorism 7: 134-46. [CrossRef]

Aiello, Emilia, Lídia Puigvert, and Tinka Schubert. 2018. Preventing violent radicalization of youth through dialogic evidence-based policies. International Sociology 33: 435-53. [CrossRef]

Aistrope, Tim. 2016. Social media and counterterrorism strategy. Australian Journal of International Affairs 70: 121-38. [CrossRef]

Al-Zewairi, Malek, and Ghazi Naymat. 2017. Spotting the Islamist Radical within: Religious Extremists Profiling in the United State. Procedia Computer Science 113: 162-69. [CrossRef]

Alamsyah, Andi Rahman, and Vedi R. Hadiz. 2017. Three Islamist generations, one Islamic state: the Darul Islam movement and Indonesian social transformation. Critical Asian Studies 49: 54-72. [CrossRef]

Alch, Mark L. 2000. The Echo-Boom Generation-A Growing Force in American Society. Futurist 34: 42-46.

Aly, Anne. 2012. An audience-focused approach to examining religious extremism online. Australian Journal of Communication 39: 1-16.

Aly, Anne, Stuart Macdonald, Lee Jarvis, and Thomas M. Chen. 2017. Introduction to the special issue: Terrorist online propaganda and radicalization. Studies in Conflict and Terrorism 40: 1-9. [CrossRef]

Amble, John Curtis. 2012. Combating terrorism in the new media environment. Studies in Conflict and Terrorism 35: 339-53. [CrossRef]

Andre, Virginie. 2012. "Neojihadism" 1 and YouTube: Patani militant propaganda dissemination and radicalization. Asian Security 8: 27-53. [CrossRef]

Benigni, Matthew C., Kenneth Joseph, and Kathleen M. Carley. 2017. Online extremism and the communities that sustain it: Detecting the ISIS supporting community on Twitter. PLoS ONE 1: 12. [CrossRef] [PubMed]

Bhui, Kamaldeep, and Yasmin Ibrahim. 2013. Marketing the "radical": symbolic communication and persuasive technologies in jihadist websites. Transcultural Psychiatry 50: 216-334. [CrossRef] [PubMed]

Bräuchler, Birgit. 2004. Islamic radicalism online: The moluccan mission of the Laskar Jihad in cyberspace. Australian Journal of Anthropology 15: 267-85. [CrossRef]

Briggs, Rachel, and Sebastien Feve. 2014. Policy Brief: Countering the Appeal of Extremism Online. London: Institute for Strategic Studies.

Bruinessen, Martin van, ed. 2013. Contemporary Developments in Indonesian Islam: Explaining the Conservative Turn. Singapore: Institute of Southeast Asian Studies.

Burke, Jason. 2011. Al-Shabab's Tweets Won't Boost Its Cause. The Guardian, December 19.

Cetina, Karin Knorr. 2005. Complex global microstructures. The new terrorist societies. Theory, Culture and Society 22: 213-34. [CrossRef]

Chiluwa, Innocent. 2015. Radicalist discourse: a study of the stances of Nigeria's Boko Haram and Somalia's Al Shabaab on Twitter. Journal of Multicultural Discourses 10: 214-35. [CrossRef]

Choudhury, Tufyal. 2007. The Role of Muslim Identity Politics in Radicalisation: A Study in Progress. In Communities and Local Government. London: Eland House. 
Conway, Maura. 2006. Terrorism and the Internet: New Media-New Threat? Parlimentary Affaris 59: $283-98$. [CrossRef]

Conway, Maura. 2017. Determining the Role of the Internet in Violent Extremism and Terrorism: Six Suggestions for Progressing Research. Studies in Conflict \& Terrorism 40: 77-98. [CrossRef]

Cottee, Simon, and Keith Hayward. 2011. Terrorist (e)motives: The existential attractions of terrorism. Studies in Conflict $\mathcal{E}$ Terrorism 34: 963-86.

Deckard, Natalie Delia, and David Jacobson. 2015. The prosperous hardliner: Affluence, fundamentalism, and radicalization in Western European Muslim communities. Social Compass 62: 412-33. [CrossRef]

Denning, Dorothy E. 2001. Activism, Hacktivism, and Cyberterrorism: The Internet as a Tool for Influencing Foreign Policy. Berkeley: The Nautilus Institute.

Doosje, Bertjan, Annemarie Loseman, and Kees van den Bos. 2013. Determinants of Radicalization of Islamic Youth in the Netherlands: Personal Uncertainty, Perceived Injustice, and Perceived Group Threat. Journal of Social Issues 69: 586-604. [CrossRef]

Drennan, Shane, and Andrew Black. 2007. Jihad Online: The Changing Role of the Internet. Jane's Intelligence Review 19: 16-20.

Farrington, David P. 2003. British Randomized Experiments on Crime and Justice. The ANNALS of The American Academy 589: 150-67. [CrossRef]

Fealy, Greg. 2007. A conservative turn: Liberal Islamic groups have prompted a backlash. Inside Indonesia 87: 35-32.

Gendron, Angela. 2017. The Call to Jihad: Charisnatic Preachers and the Internet. Studies in Conflict and Terrorism 40: 44-61. [CrossRef]

Green, Joshua, and Henry Jenkins. 2011. Spreadable Media. How Audiences Create Value and Meaning in a Networked Economy. In The Handbook of Media Audiences. Edited by Virginia Nightingsle. West Sussex: Blackwell Publishing Ltd., pp. 109-27.

Greenberg, Karen J. 2016. Counter-Radicalization via the Internet. The ANNALS of The American Academy 668: 165-79. [CrossRef]

Hegghammer, Thomas. 2012. The recruiter's dilemma: Signalling and rebel recruitment tactics. Journal of Peace Research 50: 3-16. [CrossRef]

Hwang, Julie Chernov. 2017. The Disengagement of Indonesian Jihadists: Understanding the Pathways. Terrorism and Political Violence 29: 277-95. [CrossRef]

Iqbal, Muhammad, Kerry O’Brien, Ana-Maria Bliuc, and Matteo Vergani. 2016. Death Reminders Increase Agreement With Extremist Views but Not Violent Extremist Action in Indonesian Muslims. Journal of Cross-Cultural Psychology 47: 891-97. [CrossRef]

King, Michael, and Donald M. Taylor. 2011. The radicalization of homegrown jihadists: A review of theoretical models and social psychological evidence. Terrorism and Political Violence 23: 602-22. [CrossRef]

Kirby, Aidan. 2007. The London Bombers as "Self-Starters": A Case Study in Indigenous Radicalization and the Emergence of Autonomous Cliques. Studies in Conflict \& Terrorism 30: 415-28. [CrossRef]

Klausen, Jytte J. 2015. Tweeting the Jihad: Social media networks of Western foreign fighters in Syria and Iraq. Studies in Conflict and Terrorism 38: 1-22. [CrossRef]

Kortam, Marie. 2017. From Cognitive Environment to French Youth Engagement in Jihad. Global Policy 8: 100-5. [CrossRef]

Laqueur, Walter. 1993. Europe in Our Time: A History, 1945-92. London: Penguin Books.

Levin, Brian. 2015. The Original Web of Hate: Revolution Muslim and American Homegrown Extremists. American Behavioral Scientist 59: 1609-30. [CrossRef]

Lieberman, Joseph, and Susan Collins. 2008. Violent Islamist Extremism, the Internet, and the Homegrown Terrorist Threat. Washington: United States Senate Committee on Homeland Security and Governmental Affairs.

MacDonald, Stuart, and David Mair. 2015. Terrorism Online: A New Strategic Environment. In Terrorism Online: Politics, Law and Technology. Edited by Lee Jarvis, Stuart Macdonald and Thomas M. Chen. Abingdon: Routledge, pp. 10-34.

Mair, David. 2016. \#Westgate: A Case Study: How al-Shabaab used Twitter during an Ongoing Attack. Studies in Conflict and Terrorism 40: 24-43.

Michael, George. 2013. The new media and the rise of exhortatory terrorism. Strategic Studies. Quarterly Spring 2013: 40-68. 
Mietzner, Marcus, and Burhanuddin Muhtadi. 2018. Explaining the 2016 Islamist Mobilisation in Indonesia: Religious Intolerance, Militant Groups and the Politics of Accommodation. Asian Studies Review 42: 479-97. [CrossRef]

O'Hara, Kieron, and David Stevens. 2015. Echo Chambers and Online Radicalism: Assessing the Internet's Complicity in Violent Extremism. Policy and Internet 7: 401-22. [CrossRef]

Pantucci, Raffaello. 2011. Typology of Lone Wolves: Preliminary Analysis Lone Islamist Terrorists. London: The International Centre for the Study of Radicalisation and Political Violence.

Pedersen, Willy, Viggo Vestel, and Anders Bakken. 2018. At risk for radicalization and jihadism? A population-based study of Norwegian adolescents. Cooperation and Conflict 53: 61-83. [CrossRef]

Reid, Anthony. 1967. Nineteenth Century Pan-Islam in Indonesia and Malaysia. The Journal of Asian Studies 26: 267-83. [CrossRef]

Rudner, Martin. 2017. "Electronic jihad": The internet as Al Qaeda's catalyst for global terror. Studies in Conflict and Terrorism 40: 10-23. [CrossRef]

Smith, Claire, Heather Burke, Cherrie de Leiuen, and Gary Jackson. 2016. The Islamic State's symbolic war: Daesh's socially mediated terrorism as a threat to cultural heritage. Journal of Social Archaeology 16: 164-88. [CrossRef]

Silke, Andrew. 2008. Exploring the Psychological Processes of Jihadi Radicalization. European Journal of Criminology 5: 99-123. [CrossRef]

Stenersen, Anne. 2008. The Internet: A Virtual Training Camp? Terrorism and Political Violence 20: 215-33. [CrossRef]

Tapscott, Don. 2009. Grown Up Digital. New York: McGraw Hill.

The AQ Chef. 2010. Make a Bomb in the Kitchen of Your Mom. Inspire 1: 33-40.

Weimann, Gabriel. 2005. The Theater of Terror. Journal of Aggression, Maltreatment E Trauma 9: 379-90.

Weng, Hew Wai. 2018. The Art of Dakwah: social media, visual persuasion and the Islamist propagation of Felix Siauw. Indonesia and the Malay World 46: 61-79. [CrossRef]

Wong, Mathew Y.H., Paul Vinod Khiatani, and Wing Hong Chui. 2019. Understanding youth activism and radicalism: Chinesevalues and socialization. The Social Science Journal 56: 255-67. [CrossRef] 